\title{
Notes on the narrow endemic of Armenia, Pyrus browiczii Mulk. (Rosaceae)
}

\author{
J. A. Akopian*, A. G. Ghukasyan, M. E. Oganesian \\ Institute of Botany after A. L. Takhtajyan NAS RA, Acharyan str. 1, Yerevan 0040, Armenia._E-mail: akopian_janna@inbox.ru \\ * Corresponding author
}

Keywords: Armenian flora, description, Pyrus section Pashia, Pyrus browiczii, taxonomy.

Summary. Pyrus browiczii Mulk. is a narrow endemic of the Vayots Dzor province of Armenia. It is the only pear species from the East Asian Pyrus section Pashia native to Armenian flora. Since the description by Ya. I. Mulkidzhanyan in 1969 so far $P$. browiczii was known by the type and single specimens in fruits. During the present study, P. browiczii was collected and observed in nature in flowering and fruiting phases. Article contains data on species taxonomy, ecology and particulars of habitat, complete description of the species, it is illustrated by original photos.

\section{Заметки об узколокальном эндемике Армении - Pyrus browiczii Mulk. (Rosaceae)}

\author{
Ж. А. Акопян, А. Г. Гукасян, М. Э. Оганесян \\ Институт ботаники имени А. Л. Тахтаджсяна НАН РА, ул. Ачаряна 1, г. Ереван-0040, Армения
}

Ключевые слова: описание, систематика, флора Армении, Pyrus секция Pashia, Pyrus browiczii.

Аннотация. Pyrus browiczii Mulk. является узколокальным эндемиком области Вайоц Дзор Армении. Это единственный вид груши из восточноазиатской секции Pashia, встречающийся во флоре Армении. После описания в 1969 г. Я. И. Мулкиджаняном до настоящего времени, P. browiczii был известен по типу и единичным сборам в плодах. В результате настоящего исследования были собраны новые образцы $P$. browiczii и проведены наблюдения в природе в фазе цветения и плодоношения. Статья содержит данные по таксономии, экологии и особенностях местообитания, дополненное описание вида, иллюстрирована оригинальными фотографиями.

\section{Introduction}

Armenia is a center of high diversity, polymorphism and narrow endemism in the genus Pyrus L. (Mulkidzhanyan, 1969b; Browicz, 1993). About 32-34 species of four sections, Pashia Koehne, Pyrus, Xeropyrenia Fed., Argyromalon Fed., are recognized in the Armenian flora, of which 18 species are endemics for Armenia and Southern Transcaucasia (Akopian, 2007, 2010a).

Pyrus browiczii Mulk. was first described by Ya. I. Mulkidzanyan (1969a) from the Yeghegis River gorge - a remarkable habitat with concentration of numerous pear species, located in the Vayots Dzor province of Armenia (Darelegis floristic region). According to the Herbarium collections (ERE), 16 species of the genus Pyrus grow there: P. browiczii (Pashia), P. cancasica Fed., P. demetrii Kuth., P. sosnovskyi Fed. (Pyrus), P. complexa Rubtzov, P. daralaghezii Mulk., P. elata Rubtzov, $P$. pseudosyriaca Gladkova, P. syriaca Boiss. (Xeropyrenia), P. georgica Kuth., P. gergerana Gladkova, $P$. hajastana Mulk., $P$. medvedevii Rubtzov, $P$. oxyprion Woronow, $P$. salicifolia Pall., P. takhtadzhianii Fed. (Argyromalon). All the groups of Pyrus species are represented in this 
location, reflecting the main trends of formation and speciation processes in the genus: from the ancient acute-serrate or aristate-dentate, glabrous, broad-leaved mesophilic forms to xerophytic forms of pears with narrow, small, densely pubescent leaves. The ancestors of the mesophilic species were components of the ancient tertiary forest flora, the refugia of which were preserved in East Asia. In Transcaucasia, according to V. N. Gladkova (1990), they are represented by such species as $P$. pyrifolia (Burm. f.) Nakai, P. browiczii Mulk., P. caucasica Fed., P. hyrcana Fed., P. zangezura Maleev.

Pyrus browiczii is the only pear species from the East Asian Pyrus section Pashia that grows in Armenia. It should be noted that the section Pashia is represented in the Caucasian flora rarely by single taxa: by the local variety P. pyrifolia (Burm. F.) Nakai var. talyschensis Gladkova in the Talysh flora (Gladkova, 1988) and by P. pyrifolia (Burm. f.) Nakai var. culta (Makino) Nakai in the garden culture of Transcaucasia (Fedorov, 1954).
So far, P. browiczii has been known only from type specimens, collected by J. I. Mulkidzhanyan et al. in 1968 and the later single samples in fruit stage, stored in the Herbarium (ERE) of the Department of Plant Taxonomy and Geography of the Institute of Botany NAS RA.

During expeditions in May and October of 2019 in Vayots Dzor province, $P$. browiczii was discovered in the area of "locus classicus", where new herbarium specimens were collected from. P. browiczii was described (Mulkidzhanyan, 1969a) by specimens, collected in the plant fruiting period, and the diagnosis of the species did not involve the features of inflorescences and flowers ("flowers unknown"). After the study of the existing herbarium material in ERE and comparing it with new collections of $P$. browiczii, as well as due to observations made in nature during the flowering and fruiting phase of the species, we found it necessary to supplement its description (Fig. 1).

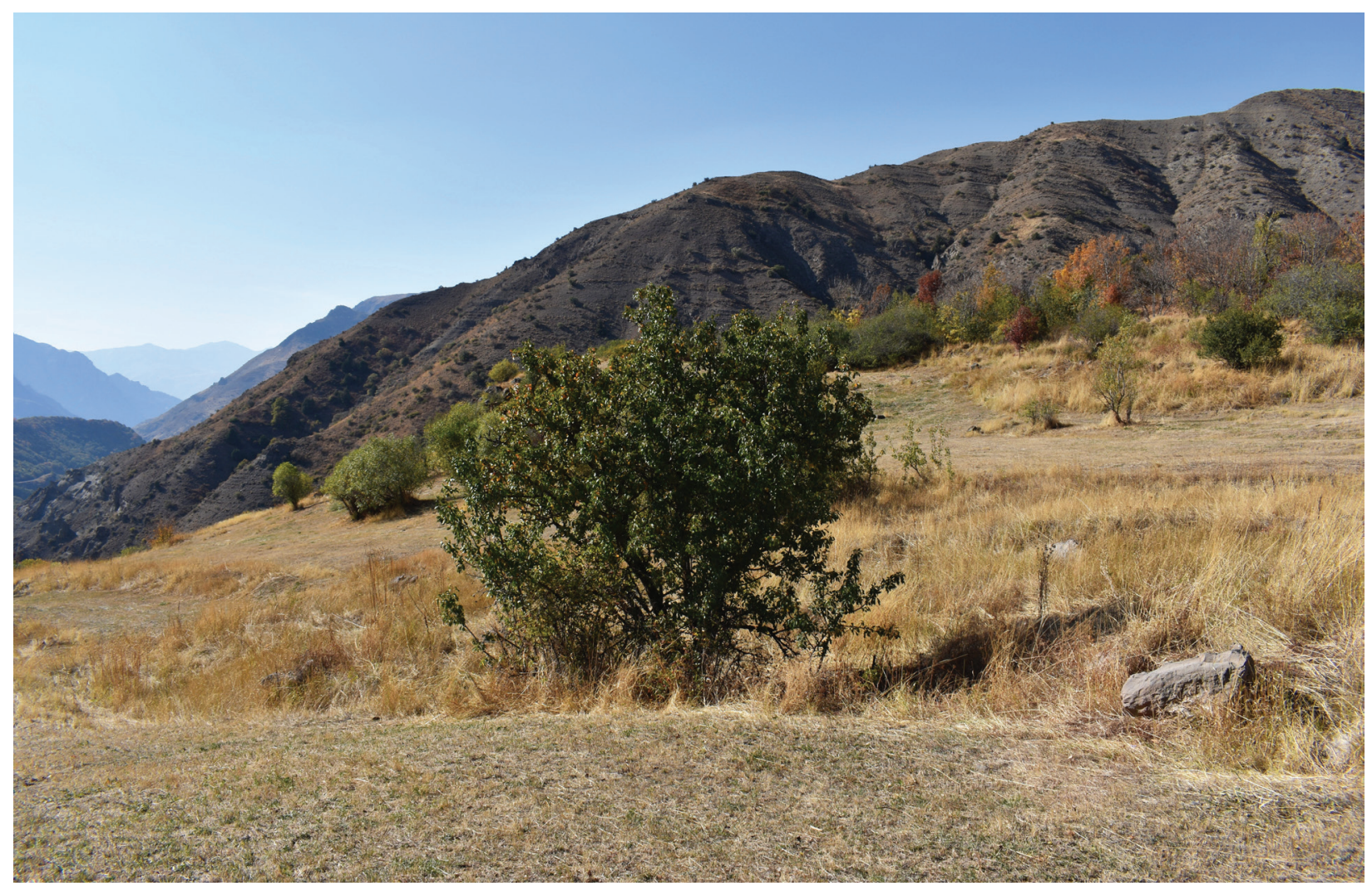

Fig. 1. View on Pyrus browiczii tree in the natural habitat.

\section{Material and methods}

The study was based on P. browiczii ERE Herbarium material and on the new materials collected from species area in the Vayots Dzor province of Armenia during expeditions in $23 \mathrm{~V} 2019$ and 11 X 2019. Materials represent both flowering and fruiting phases. Morphological characteristics of $P$. browiczii specimens were studied using Stereo Microscope MBC-9. Photos of the plant and their 
details were done with digital camera NIKON D3400.

\section{Results}

\section{Taxonomy and Description}

\section{Pyrus L.}

Section Pashia Koehne 1893, Deutsch. Dendrol: 244; emend. Terpó 1960, Ann. Acad. Horti-Viticult. 22, 6, 2: 30-32.

Calyx deciduous in fruits. Leaves ovate or orbicular, serrate or crenate, rarely entire, abruptly angustate into long, thin petioles; pubescence absent or sparse. Fruits covered with white or brownish lenticels or without them.

Type: Pyrus pashia Hamilt.

P. browiczii Mulk. 1969, Dokl. Akademii Nauk ArmSSR, 1969, 48, 4: 233.

Described from Armenia: "Armenia. Daralagez, systema fl. Elegis, inter pagos Kavuschuk et Gulliduz, 1700 m s. m. 12 VII 1968, Ja. I. Mulkidzhajan, K. K. Browicz, T. N. Popova, B. G. Arevschatjan legunt" (Fig. 2).

Distribution. Darelegis floristic region of Armenia. Gorge of the river Yeghegis, in the vicinity of villages Hermon (Kavuschuk) and Vardaovit (Gulliduz). Seldom. Narrow endemic of the Vayots Dzor province of Armenia (Fig. 3).

Ecology and Habitat. In the middle mountain belt, $1700-1950 \mathrm{~m}$ a. s. 1 , at the edges of broadleaved forests and fields, on the open hills, meadows; mostly solitary. The habitat of $P$. browiczii occurrence is rich in other woody fruit plants, e. g. Rosa corymbifera Borkh., R. spinosissima L., Malus orientalis Uglitzk., Sorbus aucuparia L., Crataegus sp., $\times$ Pyrus hyrcana Fed., P. pseudosyriaca Gladkova, P. syriaca Boiss., P. fedorovii Kuth., P. takhtadzhianii Fed. and some others.

Flowering observed in April - May, fruiting in September - October.

Protection Category. Critically endangered species, included in the Red Book of Plants of RA (Akopian, 2010b). The area of occupancy is less than $10 \mathrm{~km}^{2}$. The limiting factors are restricted extent of occurrence and area of occupancy as well as anthropogenic factors influence. The population is represented by single individuals far apart from each other. Seed productivity is low, vegetative weak propagation is noted. There are currently no measures to protect the species in the habitat. Within the present study, some seedlings of $P$. browiczii were transplanted from nature into the living collection "Flora and Vegetation of Armenia" of the Yerevan Botanical Garden NAS RA for conservation ex situ.

Description. Tree up to $15 \mathrm{~m}$ tall with trunk $25-40 \mathrm{~cm}$ in diameter, crown broadly pyramidal, branches upright directed; bark grayish-brown, almost smooth on young branches and deeply scalyfurrowed on old ones. Spines dark brown, short, $0.8-1.5 \mathrm{~cm}$ long. Buds $0.5-0.8 \mathrm{~cm}$, ovate, conical at the top, glabrous, scales broadly ovate, shortly pointed at the top. Leaves $6-8 \times 3-5 \mathrm{~cm}$, lustrous green above, paler below, thin, elliptic, at base from obtuse to broadly-cuneate, at apex broadly acute to acute, weakly mucronate, at margin unequal minute crenate-dentate; young leaf blades below along the main vein and petioles sparsely hairy, later glabrous; petioles up to $4 \mathrm{~cm}$ long; stipules $1.5-2.5 \mathrm{~mm}$ long, narrowly subulate, deciduous. Inflorescence corymb, up to $8 \mathrm{~cm}$ broad, usually 10 -flowered. Bracts 6-8 $\mathrm{mm}$ long, filiform, brownish. Flowers $2.8-3 \mathrm{~cm}$ in diameter, pedicels $4-5 \mathrm{~cm}$ long. Hypanthium (2.5) $2.8 \times(1.8) 2.3 \mathrm{~mm}$, hairy, sepals 4.5-4.8 mm long, reflexed, triangular acuminate, on both sides densely tomentose. Receptacle 4.2 $\mathrm{mm}$ in diameter, saucer-shaped, densely covered by whitish glands. Petals 5, white, from $13(15) \times 13$ to $12 \times 8 \mathrm{~mm}$, orbicular or obovate, shortly clawed at the base, free, in flowering directed apart. Stamens $20-22$, in two rows, ones of the outer row longer then inner ones, anthers (0.8)1.0 mm long, dark pink, filaments white, in outer row $5.5-6.3 \mathrm{~mm}$, in inner row 2.5-3.5 mm long. Styles 5, $5.5 \mathrm{~mm}$ long, slightly pubescent at base; ovary 5-loculed. Fruit pome, shortly pyriform, (1.5)2-4 cm long, with 5 unequal locules, brown, smooth, without lenticels; fruit pedicels up to 5-6 cm long. Calyx in fruits deciduous, leaving only a scar ring. Seeds (6) $8 \times$ (4) $6 \mathrm{~mm}$, dark brown, ovate, at apex acute, flat at one side, convex at other side (Fig. 4).

Examined specimens (Armenia, Darelegis floristic region): «Армянская ССР, Даралагез, ущ. Элегис, Кавушуг × Гюллидуз. Ближе к Гюллидузу на краю поля. 1700 м над ур. м. 12 VII 1968. Я. И. Мулкиджанян, К. К. Брович, Т. Н. Попова, Б. Г. Аревшатян. Det. J. I. Mulkijanian» (Holo ERE 146612, barcode ERE 0000832); «АрмCCP. Даралагез, ущ. Элегис, сел. Кавушуг × Гюллидуз. На краю ущелья. 1700 м над ур. м. Южн. скл. 12 VII 1968. Ja. I. Mulkijanian, K. K. Browicz, T. N. Popova, B. Arevschatjan. Det. Ja. I. Mulkijanian» (Iso - ERE 144574, barcode ERE 0000833); «АрмССР, Даралагез, ущ. р. Элегис, сел. Кавушуг х сел. Гюллидуз, слева от шоссе, среди се- 


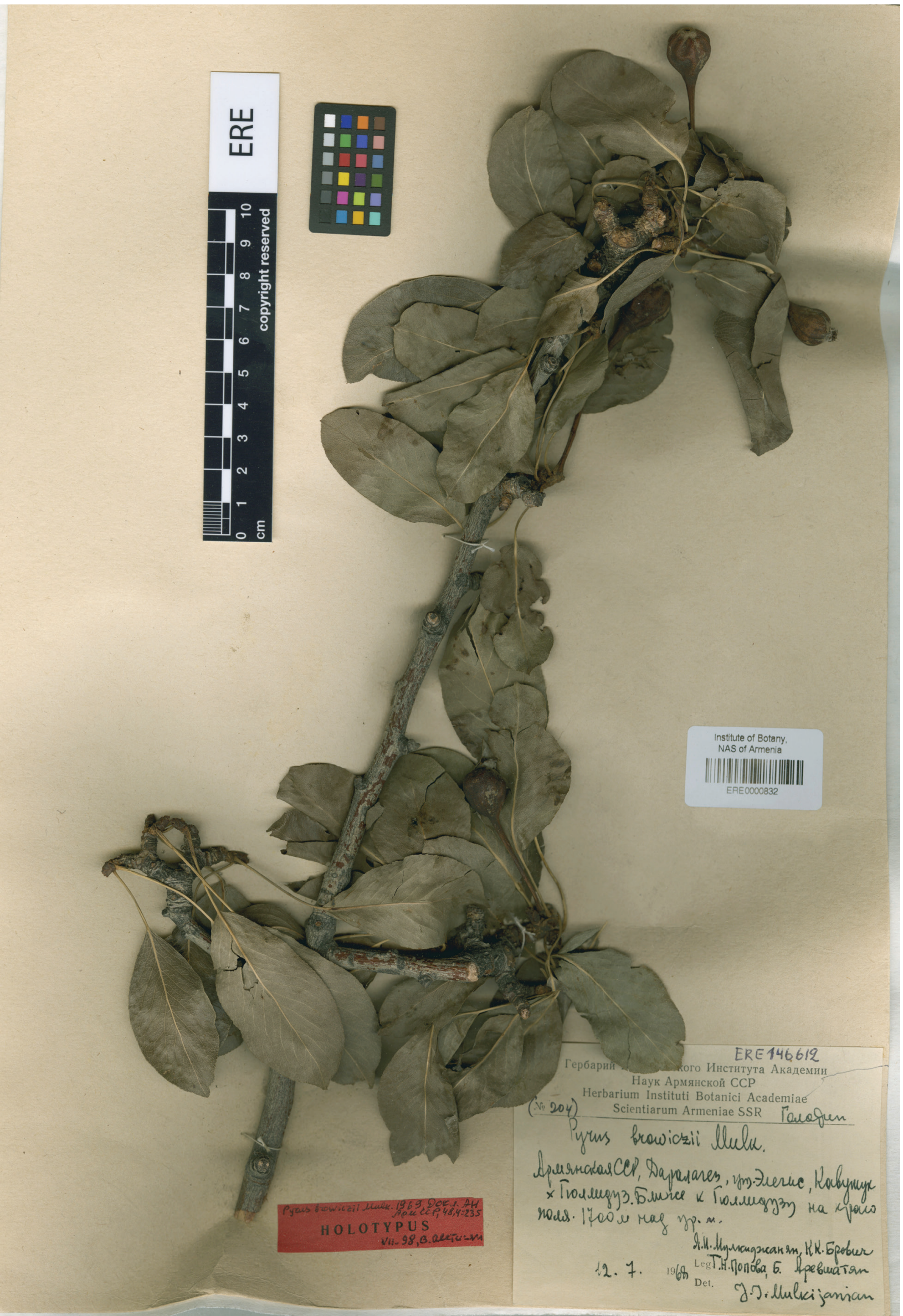

Fig. 2. Holotype of Pyrus browiczii Mulk. 
нокосного луга. 1700 м над ур. м. 11 VII 1968. Я. И. Мулкиджанян, К. К. Брович, Т. Н. Попова, Б. Г. Аревшатян. Det. Ja. I. Mulkijanian» (Sp. auth., ERE 144575, barcode ERE 0000834); «АрмССР. Даралагез, Гюллидуз. 11 VII 1968. Ja. I. Mulkijanian. Det. Ja. I. Mulkijanian» (Sp. auth., ERE 89837, barcode ERE 0000836); «АрмCCP. Даралагез, Гюллидуз. 11 VII 1968. Ja. I. Mulkijanian. Det. Ja. I. Mulkijanian» (Sp. auth., ERE 89676, barcode ERE 0000835); «АрмССР, Даралагез. Ущ. Элегис, Кавушуг-Гюллидуз. 28 VIII 1968. Я. И. Мулкиджанян. Det. Ja. I. Mulkijanian» (Sp. auth., ERE 90001, barcode ERE 0006401); «Армения, обл. Вайоцдзор, между с. с. Гермон
(Кавушуг) и Вардаовит (Гюллидуз), 1900-1950 м над ур. м. $39^{\circ} 53^{\prime} \mathrm{N}, 45^{\circ} 28^{\prime}$ Е. 31 V 2006. Э. Габриэлян, А. Нерсесян, М. Саркисян. Det. J. Akopian» (ERE 172066, barcode ERE 0006403); «Армения, обл. Вайоцдзор, между с. с. Гермон (Кавушуг) и Вардаовит (Гюллидуз), 1900-1950 м над ур. м. $39^{\circ} 53^{\prime} \mathrm{N}, 4^{\circ} 28^{\prime}$ E. 31 V 2006. Э. Габриэлян, А. Нерсесян, М. Саркисян. Det. J. Akopian» (ERE 172067, barcode ERE 0006405); «Армения, Вайоцдзорский марз, долина p. Ехегис, между с. с. Гермон и Вардаовит, 1950 м над ур. м. $39^{\circ} 53^{\prime} 05^{\prime \prime} \mathrm{N}, 45^{\circ} 27^{\prime} 49^{\prime \prime} \mathrm{E} .23 \mathrm{~V}$ 2019. Ж. Акопян, А. Гукасян, М. Оганесян, Ж. Овакимян. Det. J. Akopian» (ERE 196430-196433); «Армения,

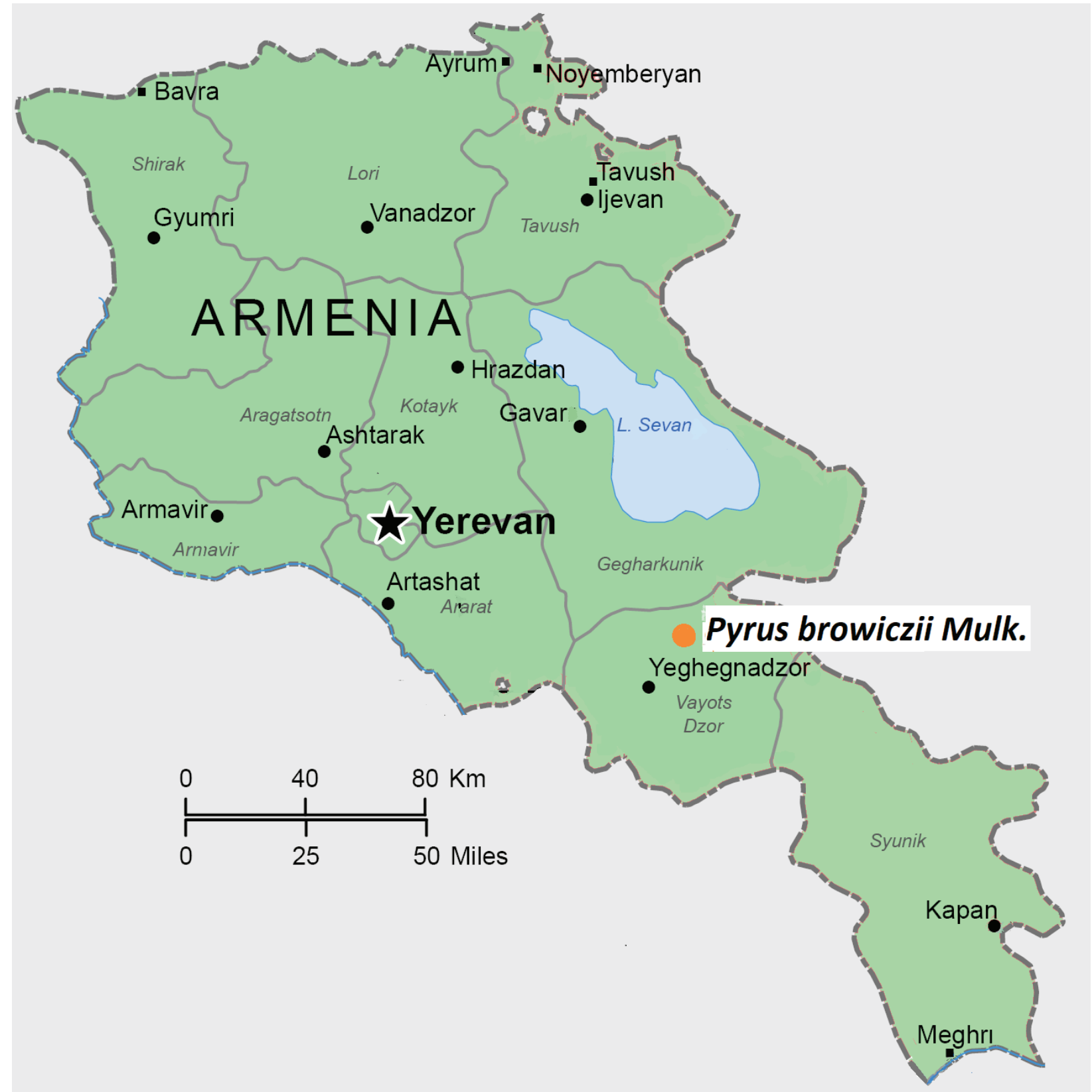

Fig. 3. Pyrus browiczii Mulk. location in the Vayots Dzor province of Armenia. 
Вайоцдзорский марз, ущелье р. Ехегис, между с. с. Гермон и Вардаовит, у поворота с родником, 1954 м над ур. м. $39^{\circ} 53^{\prime} 07,1^{\prime \prime} \mathrm{N}, 45^{\circ} 27^{\prime} 47,7^{\prime \prime}$ Е.
11 X 2019. Ж. Акопян, А. Гукасян, М. Оганесян. Det. J. Akopian» (ERE 196437-196440).
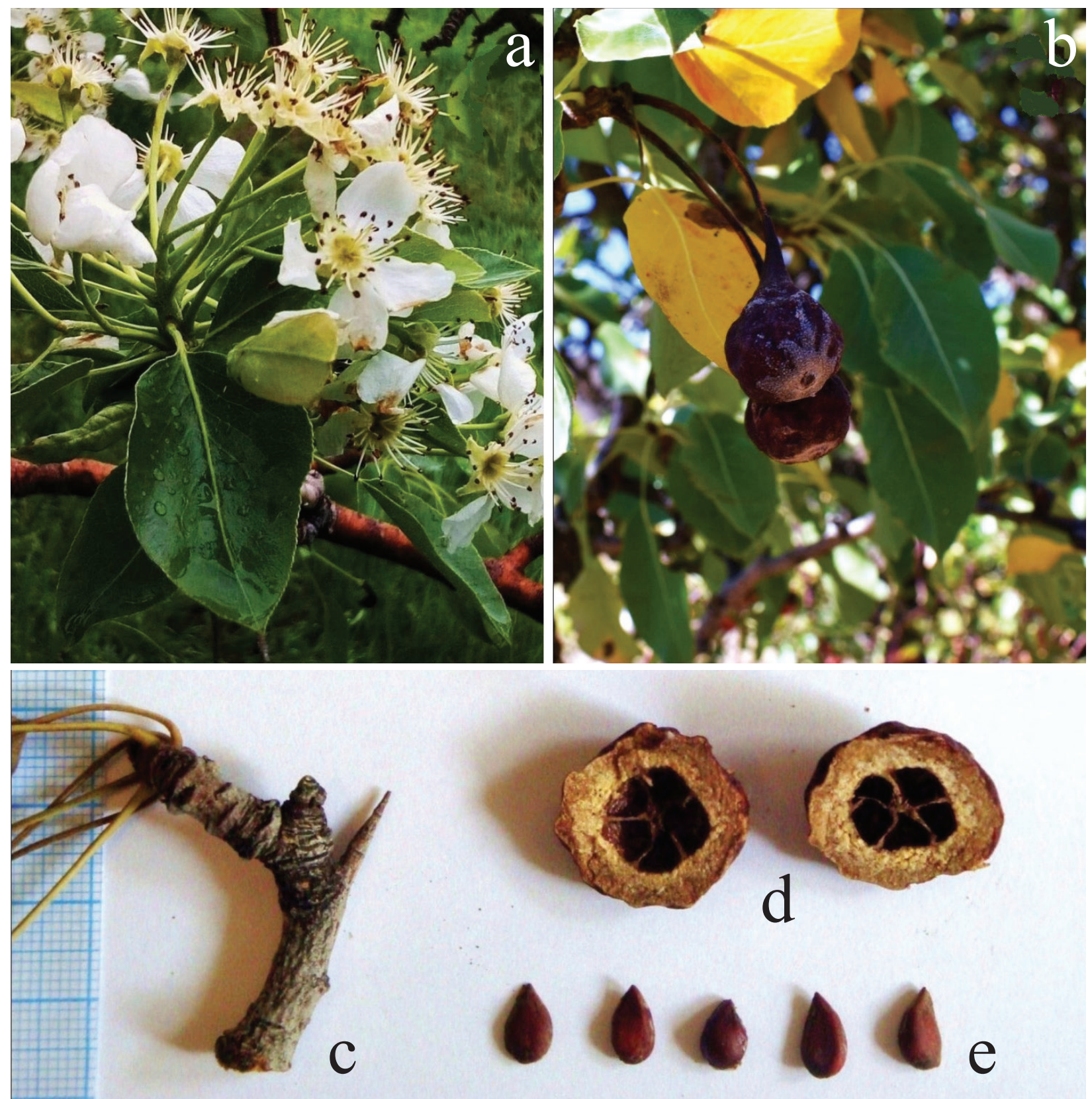

Fig. 4. Pyrus browiczii Mulk.: a - inflorescence and flowers; $\mathrm{b}$ - fruits; $\mathrm{c}$ - spine; $\mathrm{d}$ - fruit section; $\mathrm{e}$ - seeds.

\section{REFERENCES / ЛИТЕРАТУРА}

Akopian J. A. 2007. On the Pyrus L. (Rosaceae) species in Armenia. Flora, vegetation and plant resources of Armenia 16: 15-26. [In Russian] (Акопян Ж. A. О видах рода Pyrus L. (Rosaceae) в Армении // Флора, растительность и растительные ресурсы Армении, 2007. Т. 16. С. 15-26).

Akopian J. A. 2010a. Endemic pears (Pyrus L., Rosaceae) of Armenia and Southern Transcaucasia. In: Izucheniye flory Kavkaza [Study of the flora of the Caucasus. Abstracts of the International Conference]. Pyatigorsk. Pp. 9-10. [In Russian] (Акопян Ж. А. Эндемичные груши (Pyrus L., Rosaceae) Армении и Южного Закавказья // Изучение флоры Кавказа: Тезисы докладов междунар. науч. конф. Пятигорск, 2010. С. 9-10).

Akopian J. A. 2010b. Pyrus L. In: The Red Book of Plants of the Republic of Armenia. Higher plants and Fungi. Eds. K. Tamanyan, G. Fayvush, L. Nanagyulyan, T. Danielyan. Second edition. Yerevan. Pp. 435-444. 
Browicz K. 1993. Conspect and chorology of the genus Pyrus L. Arboretum Korickie 38: 17-33.

Gladkova V. N. 1988. Pyrus L. (Rosaceae) genus species of Talish flora. Novosti sistematiki vysshikh rasteniy [Novit. Syst. Pl. Vasc.] 25: 96-102. [In Russian] (Гладкова В. Н. Виды рода Pyrus L. (Rosaceae) флоры Талыша // Новости сист. высш. раст., 1988. Т. 25. С. 96-102).

Gladkova V. N. 1990. The synopsis of the species of the genus Pyrus (Rosaceae) for the flora of the Caucasus. Bot. Zhurn. (Moscow \& St. Petersburg) 75(6): 874-883. [In Russian] (Гладкова В. Н. Обзор видов рода Pуrus (Rosaсеае) флоры Кавказа // Бот. журн., 1990. Т. 75. № 6. С. 874-883).

Fedorov An. A. 1954. Pyrus L. In: Derevya i kustarniki SSSR [Trees and shrubs of USSR]. Vol. 3. Ed. S. Ya. Sokolov. Moscow-Leningrad. Pp. 378-414. [In Russian] (Федоров Ан. А. Ругиs L. // Деревья и кустарники СССР. Т. 3. Под ред. С. Я. Соколова. М.-Л., 1954. С. 378-414).

Koehne B. A. E. 1893. Deutsche Dendrologie. Sttutgart: Verlag von Ferdinand Enke. 601 pp.

Mulkidzhanyan Ya. I. 1969a. New for science species of pears from Southern Transcaucasia. Doklady Akademii Nauk Armyanskoy SSR [Repors of Academy of Sciences of Armenian SSR] 48, 4: 234-236. [In Russian] (Мулкиджанян Я. И. Новые для науки виды груши из Южного Закавказья // Доклады Академии Наук Армянской ССР, 1969a. Т. 48, № 4. С. 234-236).

Mulkidzhanyan Ya. I. 1969b. Armenian SSR - one of the centers of speciation in the genus Pyrus. Doklady Akademii Nauk Armyanskoy SSR [Reports of Academy of Sciences of Armenian SSR] 48, 5: 288-291. [In Russian] (Myлкиджанян Я. И. Армянская ССР - один из очагов видообразования в роде Pyrus // Доклады Академии Наук Армянской ССР, 1969b. Т. 48, № 5. С. 288-291).

Terpó A. 1960. Magyarorszâg Vadkörtéi (Pyri Hungariae). Annal. Acad. Hort. Viticult. 6: 1-258. 